\title{
PENERAPAN METODE BOOTSTRAP RESIDUAL DALAM MENGATASI BIAS PADA PENDUGA PARAMETER ANALISIS REGRESI
}

\author{
Ni Made Metta Astari ${ }^{\S 1}$, Ni Luh Putu Suciptawati ${ }^{2}$, Komang Gde Sukarsa ${ }^{3}$
}

\footnotetext{
${ }^{1}$ Jurusan Matematika, Fakultas MIPA - Universitas Udayana [Email: astari.metta@gmail.com]

${ }^{2}$ Jurusan Matematika, Fakultas MIPA - Universitas Udayana [Email: putusuciptawati@yahoo.co.id]

${ }^{3}$ Jurusan Matematika, Fakultas MIPA - Universitas Udayana [Email: sukarsakomang@yahoo.com]

${ }^{\S}$ Corresponding Author
}

\begin{abstract}
Statistical analysis which aims to analyze a linear relationship between the independent variable and the dependent variable is known as regression analysis. To estimate parameters in a regression analysis method commonly used is the Ordinary Least Square (OLS). But the assumption is often violated in the OLS, the assumption of normality due to one outlier. As a result of the presence of outliers is parameter estimators produced by the OLS will be biased. Bootstrap Residual is a bootstrap method that is applied to the residual resampling process. The results showed that the residual bootstrap method is only able to overcome the bias on the number of outliers 5\% with 99\% confidence intervals. The resulting parameters estimators approach the residual bootstrap values OLS initial allegations were also able to show that the bootstrap is an accurate prediction tool.
\end{abstract}

Keywords: regression analysis, outlier, biases, bootstrap residuals

\section{PENDAHULUAN}

Analisis statistik yang bertujuan untuk menganalisa suatu hubungan linier antara peubah bebas $(x)$ dan peubah tak bebas $(y)$ dikenal dengan analisis regresi. Istilah regresi pertama kali dikembangkan oleh Sir Francis Galton di akhir abad ke-19.

Analisis regresi linier sederhana merupakan analisis regresi yang melibatkan hanya satu peubah bebas dan satu peubah tak bebas [1]. Model untuk analisis regresi linier sederhana dapat dituliskan sebagai berikut:

$$
Y_{i}=\beta_{0}+\beta_{1} X_{i}+\varepsilon_{i}
$$

Untuk menduga parameter dalam analisis regresi, metode yang umum digunakan adalah Metode Kuadrat Terkecil (MKT). MKT dapat digunakan apabila asumsi-asumsi pada analisis regresi terpenuhi. Salah satu asumsi penting yang harus dipenuhi adalah asumsi kenormalan.
Namun sering kali asumsi kenormalan tersebut dilanggar pada data yang mengandung pencilan.

Pencilan merupakan suatu data amatan yang ekstrim [1]. Pencilan tidak dapat dibuang diabaikan, karena mungkin pencilan tersebut memberikan informasi penting yang tidak bisa diberikan oleh data lainnya. Akibat dari adanya pencilan adalah penduga parameter yang dihasilkan oleh MKT akan bersifat bias. Bias pada penduga parameter akan mengakibatkan penduga yang dimiliki kehilangan sifat Best Linear Unbiased Estimator (BLUE).

Bootstrap merupakan metode simulasi berbasis data yang digunakan dalam pendugaan parameter dan penyusunan selang kepercayaan tanpa perlu mengetahui distribusi populasi dari sampel yang dimiliki. Metode bootstrap pertama kali diperkenalkan oleh Efron pada tahun 1979. Nama bootstrap sendiri diambil 
dari sebuah frase "to pull oneself up by one's bootstraps" yang berarti berdiri di atas kaki sendiri [2]. Pendekatan pada bootstrap ini menggunakan metode pengambilan sampel berulang (resample).

Berdasarkan karakteristik metode bootstrap yang merupakan metode simulasi berbasis data dan tanpa mengetahui distribusi populasi dari sampel yang dimiliki, penulis ingin mengetahui apakah metode bootstrap residual mampu dalam mengatasi bias pada penduga parameter akibat adanya pencilan pada bagian bawah gugus data pada analisis regresi linier.

\section{TINJAUAN PUSTAKA}

\subsection{Metode Kuadrat Terkecil}

Metode Kuadrat Terkecil (MKT) atau Ordinary Least Square (OLS) adalah salah satu metode yang paling umum digunakan dalam analisis regresi yang bertujuan untuk meminimumkan kuadrat kesalahan $\varepsilon_{i}$ sehingga nilai regresinya mendekati nilai yang sesungguhnya. MKT merupakan metode yang digunakan untuk mendapatkan penduga yang baik bagi parameter regresi $\beta_{0}$ dan $\beta_{1}$ [1].

Agar menjadi penduga yang baik maka penduga MKT harus memiliki ukuran tingkat akurasi penduga parameter, yaitu [1]:

a. Bersifat linier

$$
\begin{aligned}
& b 1=\sum_{i=1}^{n} k_{i} Y_{i} \\
& b 0=\sum_{i=1}^{n} C_{i} Y_{i}
\end{aligned}
$$

b. Tidak bias

$$
\begin{aligned}
& E\left\{b_{1}\right\}=\beta_{1} \\
& E\left\{b_{0}\right\}=\beta_{0}
\end{aligned}
$$

c. Selang Kepercayaan Penduga

Parameter

Selang kepercayaan untuk $b_{1}$ $b_{1} \pm t(1-\alpha / 2 ; n-2) s\left\{b_{1}\right\}$

$$
\begin{aligned}
& \text { Selang kepercayaan untuk } b_{0} \\
& b_{0} \pm t(1-\alpha / 2 ; n-2) s\left\{b_{0}\right\}
\end{aligned}
$$

\subsection{Bootstrap Residual}

Bootstrap residual merupakan metode simulasi berbasis data yang proses resamplingnya diterapkan pada residual yang dihasilkan oleh model analisis regresi [2].

Sampel bootstrap residual didefinisikan sebagai suatu sampel acak berukuran $n$ yang diambil dari $\hat{F}, \quad$ misalkan $e^{*}=\left(e_{1}^{*}, e_{2}^{*}, \ldots, e_{n}^{*}\right)$, atau dapat dinyatakan sebagai berikut[2]:

$$
\widehat{F} \rightarrow\left(e_{1}^{*}, e_{2}^{*}, \ldots, e_{n}^{*}\right)=e^{*}
$$

Langkah-langkah dalam bootstrap residual sebagai berikut [3]:

1. Menentukan nilai $\hat{Y}$ dari penduga parameter yang dihasilkan oleh MKT. $\hat{Y}$ diperoleh dengan perhitungan

$$
\hat{Y}=\widehat{\beta_{0}}+\widehat{\beta_{1} X} \text {. }
$$

2.Menentukan model regresi linier sehingga menghasilkan residual. Nilai residual diperoleh dengan menghitung selisih antara $Y_{i}$ dan $\hat{Y}$ yaitu,

$$
e=Y_{i}-\hat{Y} \text {. }
$$

3.Mengambil $n$ sampel acak dengan pengembalian dari $e_{1}, e_{2}, \ldots, e_{n}$ sehingga menghasilkan $e^{*}=\left(e_{1}^{*}, e, \ldots, e_{n}^{*}\right)$.

4.Menghitung nilai bootstrap untuk $Y^{*}$ dengan menambahkan $e^{*}$ sehingga menghasilkan:

$$
Y^{*}=\beta_{0}+\beta_{1} X+e^{*}
$$

5.Menghitung koefisien regresi untuk sampel bootstrap $Y^{*}$ dengan $X$ sehingga diperoleh $\widehat{\beta}^{*}$.

6.Ulangi langkah 2,3 , dan 4 sesuai dengan jumlah replikasi yang diinginkan.

\section{METODE PENELITIAN}

Penelitian ini diawali dengan membangkitkan data simulasi dengan parameter regresi $\beta_{0}$ dan $\beta_{1}$ sehingga membentuk model regresi linier sederhana. 
Data simulasi terdiri dari satu peubah bebas dan galat yang kemudian digunakan untuk menentukan peubah tak bebas. Peubah bebas dibangkitkan sesuai model regresi linier sederhana. Membangkitkan data simulasi dilakukan dengan bantuan program R-2.15.3

Langkah-langkah membangkitkan data simulasi univariat adalah sebagai berikut:

a. Menentukan peubah bebas ( $X$ ) sebanyak 60 amatan, berupa 60 bilangan asli pertama, yaitu $1,2,3, \ldots, 60$.

b.Membangkitkan nilai sisaan ( $\varepsilon$ ) yang berdistribusi normal dengan rataan 0 dan ragam 1. Nilai sisaan yang dibangkitkan berukuran 60 .

c. Menentukan hubungan dari peubah tak bebas dan peubah bebas yaitu $Y=\beta_{0}+\beta_{1} X+\varepsilon$. Nilai parameter yang digunakan adalah $\beta_{0}=2 \operatorname{dan} \beta_{1}=1,3$, dan 5 .

d.Menentukan nilai-nilai $Y$ dari bentuk hubungan pada langkah $(c)$.

Pembangkitan data sisaan yang mengandung pencilan pada data simulasi dibagi menjadi 3 kelompok, yaitu 5\%, 10\%, dan $15 \%$ adalah sebagai berikut:

a.Pembangkitan data sisaan yang mengandung pencilan sebesar $5 \%$, yaitu dengan jumlah data 5\% dari 60 data, rataan 5 dan standar deviasi 0,1 .

b.Pembangkitan data sisaan yang mengandung pencilan sebesar $10 \%$, yaitu dengan jumlah data $10 \%$ dari 60 data, rataan 5 dan standar deviasi 0,1 .

c. Pembangkitan data sisaan yang mengandung pencilan sebesar $15 \%$, yaitu dengan jumlah data $15 \%$ dari 60 data, rataan 5 dan standar deviasi 0,1 .

Data simulasi kemudian diuji asumsi kenormalannya dengan uji Anderson-Darling, dan dengan diagram pencar untuk melihat kembali pencilan yang telah dibangkitkan dengan bantuan program R-2.15.3. Nilai $p$ value pada Uji Anderson-Darling akan dibandingkan dengan $\alpha$ sebesar 0,05 .

Hipotesis yang digunakan adalah:

$H_{0}$ : data mengikuti sebaran normal

$H_{1}$ : data tidak mengikuti sebaran normal

Keputusan menolak $H_{0}$ jika $p$-value lebih kecil dari $\alpha$.
Selanjutnya penduga parameter $\beta_{0}$ dan $\beta_{1}$ pada data simulasi akan diduga dengan MKT dan untuk melihat bias dari penduga parameter, akan diuji dengan selang kepercayaan 95\% dan 99\%. Pendugaan parameter $\beta_{0}$ dan $\beta_{1}$ akan diduga kembali dengan metode bootstrap residual dengan resampling sebanyak 250, 500, $1.000,5.000,10.000,50.000,75.000$, dan 100.000 kali. Bias dari penduga parameter akan diuji dengan seang kepercyaan bootstrap, dan asumsi kenormalannya akan diuji kembali dengan uji Anderson-Darling. Hasil dari pendugaan dengan kedua metode tersebut kemudian akan dianalisa dan dibandingkan.

\section{HASIL DAN PEMBAHASAN}

\section{A. Membangkitkan Data Simulasi}

Dalam penelitian ini data yang digunakan adalah data simulasi yang dibangkitkan dengan bantuan program R-2.15.3. Data yang dibangkitkan adalah data univariat yaitu dengan peubah tak bebas (Y) dan peubah bebas (X) sehingga bentuk hubungannya seperti pada persamaan (1) sebagai berikut:

$$
Y_{i}=\beta_{0}+\beta_{1} X_{i}+\varepsilon_{i}
$$

dengan $\varepsilon_{i}$ adalah nilai sisaan yang berdistribusi normal dengan ragam 1 dan rataan 0 . Peubah bebas $(\mathrm{X})$ yang dibangkitkan merupakan nilai konstanta yang ditentukan nilainya dan dalam penelitian ini nilai peubah bebas $(\mathrm{X})$ bernilai: $1,2,3, \ldots, 60$. Peubah tak bebas $(\mathrm{Y})$ diperoleh dengan terlebih dahulu memisalkan nilai parameternya. Nilai parameter yang digunakan adalah $\beta_{0}=2$ dan $\beta_{1}=1,3$, dan 5. Dari nilai yang diketahui yaitu dari peubah bebas (X) dan parameternya maka diperoleh nilai untuk peubah tak bebas (Y) sesuai dengan bentuk hubungan pada (1). Data awal adalah nilai dari peubah tak bebas (Y), peubah bebas (X) dan sisaan $\left(\varepsilon_{i}\right)$ merupakan data awal yang belum mengandung pencilan.

Simulasi pada data kemudian dilakukan dengan memasukkan pencilan sebesar 5\%, $10 \%$, dan $15 \%$ pada data awal yang tidak mengandung pencilan. Nilai pencilan yang 
digunakan pada penelitian ini diperoleh dengan memasukkan nilai sisaan dari sebaran normal dengan rataan 5 dan standar deviasi 0,1 $(\mathrm{N}(5 ; 0,1))$ ke dalam kelompok data sisaan awal dari sebaran data normal dengan ragam 1 dan rataan $0(\mathrm{~N}(0,1))$.

Data yang telah dibangkitkan baik data awal tanpa pencilan maupun data yang telah mengandung pencilan, selanjutnya dianalis menggunakan diagram pencar dengan bantuan program R-2.15.3. Tahapan ini dimaksudkan hanya untuk memeriksa kembali apakah data simulai mengandung pencilan atau tidak. Pada diagram pencar, adanya pencilan akan ditunjukkan dengan adanya data amatan yang tidak berada pada garis regresi. Nilai yang akan dianalisis adalah nilai variabel $x$ dan $y$ sebelum dan sesudah dimasukkan pencilan.

B. Hasil Pengujian Asumsi Kenormalan dengan Uji Anderson-Darling dan Pendugaan Parameter $\beta_{1}$ dengan MKT

Tabel 1. Hasil Pengujian Asumsi Kenormalan dengan Uji Anderson-Darling

\begin{tabular}{|c|c|c|c|}
\hline Jumlahpencilan & Alpha $(\alpha)$ & $p$-value & Keputusan \\
\hline \multicolumn{4}{|c|}{$\beta_{1}=1$} \\
\hline Tanpa P. & 0,05 & 0,4151 & Nomal \\
\hline P.5\% & 0,05 & 0,0001542 & Tidaknomal \\
\hline P.10\% & 0,05 & $6,635 \mathrm{e}-07$ & Tidaknomal \\
\hline P.15\% & 0,05 & $1,618 \mathrm{e}-08$ & Tidak nomal \\
\hline \multicolumn{5}{|c|}{$\beta_{1}=3$} \\
\hline Tanpa P. & 0,05 & 0,2094 & Normal \\
\hline P.5\% & 0,05 & $1,849 \mathrm{e}-05$ & Tidak nomal \\
\hline P.10\% & 0,05 & $2,115 \mathrm{e}-07$ & Tidak nomal \\
\hline P.15\% & 0,05 & $2,098 \mathrm{e}-09$ & Tidak nomal \\
\hline \multicolumn{4}{|c|}{$\beta_{1}=5$} \\
\hline Tanpa P. & 0,05 & 0,5039 & Normal \\
\hline P.5\% & 0,05 & $1 \mathrm{e}-04$ & Tidak nomal \\
\hline P.10\% & 0,05 & $2,087 \mathrm{e}-07$ & Tidak nomal \\
\hline P.15\% & 0,05 & $4,748 \mathrm{e}-10$ & Tidak nomal \\
\hline
\end{tabular}

Sesuai hasil uji kenormalan dengan Uji Anderson-Darling, dapat dilihat pada tabel 1 bahwa pada data dengan nilai parameter $\beta_{1}=1$, $\beta_{1}=3$, dan $\beta_{1}=5$, data tanpa pencilan memiliki $p$-value yang lebih besar dari nilai $\alpha$ sebesar
0,05 , ini menunjukkan bahwa data awal tanpa pencilan mengikuti sebaran normal. Sedangkan pada data dengan nilai $\beta_{1}=1, \beta_{1}=3$, dan $\beta_{1}=5$, data yang memiliki pencilan sebesar $5 \%, 10 \%$, dan $15 \%$, memiliki nilai $p$-value yang lebih kecil dari $\alpha$ sebesar 0,05 , ini menunjukkan bahwa data yang mengandung pencilan tidak mengikuti sebaran normal.

Berdasarkan Tabel 2 dapat dilihat bahwa pada data simulasi dengan nilai $\beta_{1}=1, \beta_{1}=3$, dan $\beta_{1}=5$ untuk data tanpa pencilan, nilai parameter $\beta_{1}$ terkandung di dalam selang kepercayaan $95 \%$ dan $99 \%$. Hal ini berarti penduga parameter regresi yang dihasilkan oleh MKT tidak mengalami bias. Di lain pihak untuk data berpencilan $5 \%$ pada $\beta_{1}=1$ dan $\beta_{1}=3$, penduga parameter tidak bias pada selang kepercayaan 99\%. Pada data berpencilan $10 \%$ dan $15 \%$, selang kepercayaan yang dihasilkan tidak memuat nilai parameter, sehingga penduga parameter $\beta_{1}$ yang dihasilkan mengalami bias.

Tabel 2. Pendugaan Parameter dengan MKT

\begin{tabular}{|c|c|c|c|c|c|}
\hline \multirow{2}{*}{$\begin{array}{l}\text { Jumlah } \\
\text { pencilan }\end{array}$} & \multirow{2}{*}{$\hat{\beta}_{1}$} & \multicolumn{2}{|c|}{ Selang kepercavaan $95 \%$} & \multicolumn{2}{|c|}{ Selangkepercaxaan $99 \%$} \\
\hline & & \begin{tabular}{c}
\multicolumn{1}{c}{ Selang } \\
kepercayaan
\end{tabular} & Keterangan & \begin{tabular}{c|} 
Selang \\
kepercayaan
\end{tabular} & Keterangan \\
\hline \multicolumn{6}{|c|}{$\beta_{1}=1$} \\
\hline Tanpa $P$. & 0,998 & $0,984-1,0127$ & Tidak Bias & $0,979 \cdot 1,017$ & Tidak Bias \\
\hline P.5\% & 0,976 & $0,956 \cdot 0,996$ & Bias & $0,949 \cdot 1,003$ & Tidak Bias \\
\hline P.10\% & 0,956 & $0,933 \cdot 0,979$ & Bias & $0,925 \cdot 0,986$ & Bias \\
\hline P.15\% & 0,940 & $0,915 \cdot 0,965$ & Bias & $0,907 \cdot 0,973$ & Bias \\
\hline \multicolumn{6}{|c|}{$\beta_{1}=3$} \\
\hline Tanpa $P$. & 2,996 & $2,979 \cdot 3,013$ & Tidak Bias & $2,974-3,019$ & Tidak Bias \\
\hline$P .5 \%$ & 2,973 & $2,951.2,995$ & Bias & $2,944-3,002$ & Tidak Bias \\
\hline P.10\% & 2,951 & $2,927-2,975$ & Bias & $2,919 \cdot 2,983$ & Bias \\
\hline P.15\% & 2,934 & $2.909 \cdot 2.959$ & Bias & $2,900-2.967$ & Bias \\
\hline \multicolumn{6}{|c|}{$\beta_{1}=5$} \\
\hline Tanpa $P$. & 4,999 & $4,981 \cdot 5,016$ & Tidak Bias & $4,976 \cdot 5,022$ & Tidak Bias \\
\hline $8.5 \%$ & 4,969 & $4,948 \cdot 4,990$ & Bias & $4,941 \cdot 4,997$ & Bias \\
\hline P.10\% & 4,951 & $4,927 \cdot 4,974$ & Bias & $4,919 \cdot 4,982$ & Bias \\
\hline$P .15 \%$ & 4,932 & $4,908 \cdot 4,957$ & Bias & $4,900-4,965$ & Bias \\
\hline
\end{tabular}


C. Pendugaan Parameter $\beta_{1}$ dengan Metode Bootstrap Residual dan Uji Asumsi

Kenormalan dengan Uji Anderson-Darling

Berdasarkan Tabel 3 data simulasi dengan nilai $\beta_{1}=1$, pada data berpencilan $5 \%$, selang kepercayaan $95 \%$ dan $99 \%$ yang dihasilkan metode bootstrap residual memuat nilai parameter $\beta_{1}$ sehingga penduga yang dihasilkan tidak mengalami bias. Di lain pihak data berpencilan 10\% dan 15\% dengan jumlah resampling yang sama, penduga parameter yang dihasilkan mengalami bias.

Tabel 3. Pendugaan Parameter $\beta_{1}=1$ dengan Bootstrap Residual

\begin{tabular}{|c|c|c|c|c|c|}
\hline \multirow{2}{*}{$\begin{array}{l}\text { Jumlah } \\
\text { pencilan }\end{array}$} & \multirow{2}{*}{$\widehat{\beta_{1}}$} & \multicolumn{2}{|c|}{ Selang kepercayaan $95 \%$} & \multicolumn{2}{|c|}{ Selangkepercayaan $99 \%$} \\
\hline & & $\begin{array}{c}\text { Selang } \\
\text { keppercayaan }\end{array}$ & Keterangan & $\begin{array}{c}\text { Selang } \\
\text { kepercayaan }\end{array}$ & Keterangan \\
\hline \multicolumn{6}{|c|}{$B=250$} \\
\hline P.5\% & 0.976 & $0,949 \cdot 1,004$ & 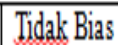 & $0,941 \cdot 1,012$ & Tidak Bias \\
\hline P.10\% & 0,956 & $0,927 \cdot 0,985$ & Bias & $0,918 \cdot 0,994$ & Bias \\
\hline P.15\% & 0,934 & $0,906 \cdot 0,963$ & Bias & $0,897-0,972$ & Bias \\
\hline \multicolumn{6}{|c|}{$B=500$} \\
\hline P.5\% & 0,976 & $0,949-1,003$ & Tidak Bias & $0,940-1,011$ & Tidak Bias \\
\hline P.10\% & 0,956 & $0,926 \cdot 0,984$ & Bias & $0,917 \cdot 0,993$ & Bias \\
\hline P.15\% & 0,934 & $0,905 \cdot 0,961$ & Bias & $0,897 \cdot 0,969$ & Bias \\
\hline \multicolumn{6}{|c|}{$B=1.000$} \\
\hline$P .5 \%$ & 0,976 & $0,948 \cdot 1,003$ & Tidak Bias & $0,940-1,011$ & Tidak Bias \\
\hline P.10\% & 0,956 & $0,927 \cdot 0,985$ & Bias & $0,918 \cdot 0,994$ & Bias \\
\hline P.15\% & 0,934 & $0,905 \cdot 0,961$ & Bias & $0,896 \cdot 0,970$ & Bias \\
\hline \multicolumn{6}{|c|}{$\mathrm{B}=5.000$} \\
\hline P..$\%$ & 0,976 & $0,949-1,002$ & Tidak Bias & $0,940 \cdot 1,010$ & Tidak Bias \\
\hline P.10\% & 0,956 & $0,926 \cdot 0,985$ & Bias & $0,916 \cdot 0,994$ & Bias \\
\hline P.15\% & 0,934 & $0,906 \cdot 0,962$ & Bias & $0,897-0,970$ & Bias \\
\hline
\end{tabular}

\begin{tabular}{|c|c|c|c|c|c|}
\hline \multicolumn{6}{|c|}{$B=10.000$} \\
\hline P.5\% & 0,976 & $0,948-1,002$ & Tidak Bias & $0,940 \cdot 1,010$ & Tidak Bia: \\
\hline P.10\% & 0,956 & $0,926 \cdot 0,986$ & Bias & $0,916 \cdot 0,995$ & Bias \\
\hline P.15\% & 0,934 & $0,906 \cdot 0,962$ & Bias & $0,897 \cdot 0,970$ & Bias \\
\hline \multicolumn{6}{|c|}{$\mathrm{B}=50.000$} \\
\hline P.5\% & 0,976 & $0,949 \cdot 1,002$ & Tidak Bias & $0,940-1,011$ & Tidak Bia: \\
\hline P.10\% & 0,956 & $0,926 \cdot 0,985$ & Bias & $0,916 \cdot 0,995$ & Bias \\
\hline P.15\% & 0,934 & $0,906 \cdot 0,961$ & Bias & $0,898 \cdot 0,970$ & Bias \\
\hline \multicolumn{6}{|c|}{$B=75.000$} \\
\hline P.5\% & 0,976 & $0,949 \cdot 1,002$ & Tidak Bias & $0,940 \cdot 1,011$ & Tidak Bia: \\
\hline P.10\% & 0,956 & $0,926 \cdot 0,986$ & Bias & $0,917 \cdot 0,995$ & Bias \\
\hline P.15\% & 0,934 & $0,9068 \cdot 0,9619$ & Bias & $0,898-0,970$ & Bias \\
\hline \multicolumn{6}{|c|}{$B=100.000$} \\
\hline P.5\% & 0,976 & $0,949 \cdot 1,002$ & Tidak Bias & $0,940-1,011$ & Tidak Bia: \\
\hline P.10\% & 0,956 & $0,926 \cdot 0,986$ & Bias & $0,917 \cdot 0,995$ & Bias \\
\hline P.15\% & 0,934 & $0,906 \cdot 0,961$ & Bias & $0,897 \cdot 0,970$ & Bias \\
\hline
\end{tabular}

Pada Tabel 4 dapat dilihat bahwa pada data simulasi dengan pencilan $5 \%$ setelah diresampling dengan metode bootstrap residual, selang kepercayaan $99 \%$ yang dihasilkan memuat nilai parameter sehingga dapat disimpulkan bahwa penduga parameter yang dihasilkan tidak bias. Pada data simulasi berpencilan $5 \%$ pada selang kepercayaan $95 \%$ dan pada data berpencilan $10 \%$ dan $15 \%$ pada selang kepercayaan $95 \%$ dan $99 \%$ menghasilkan penduga parameter yang bias.

Pada Tabel 5 dapat dilihat bahwa pada data simulasi dengan pencilan 5\%, selang kepercayaan $99 \%$ yang dihasilkan oleh metode bootstrap residual memuat nilai parameter sehingga penduga parameter yang dihasilkan tidak bias. 
Tabel 4. Pendugaan Parameter $\beta_{1}=3$ dengan Bootstrap Residual

\begin{tabular}{|c|c|c|c|c|c|}
\hline \multirow{2}{*}{$\begin{array}{l}\text { Jumlah } \\
\text { pencilan }\end{array}$} & \multirow{2}{*}{$\widehat{\beta_{1}}$} & \multicolumn{2}{|c|}{ Selang kepercayaan $95 \%$} & \multicolumn{2}{|c|}{ Selang kepercayaan $99 \%$} \\
\hline & & \begin{tabular}{c|} 
Selang \\
kepercayaan
\end{tabular} & Keterangan & \begin{tabular}{|c|} 
Selang \\
kepercayyaan
\end{tabular} & Keterangan \\
\hline \multicolumn{6}{|c|}{$B=250$} \\
\hline P.5\% & 2,970 & $2,946-2,995$ & Bias & $2,938-3,003$ & Tidak Bias \\
\hline P.10\% & 2,951 & $2,925-2,976$ & Bias & $2,917-2,984$ & Bias \\
\hline P.15\% & 2,934 & $2,910-2,959$ & Bias & $2,903-2,966$ & Bias \\
\hline \multicolumn{6}{|c|}{$B=500$} \\
\hline P.5\% & 2,970 & $2,947-2,994$ & Bias & $2,940-3,001$ & Tidak Bias \\
\hline P.10\% & 2,951 & $2,924-2,978$ & Bias & $2,916-2,986$ & Bias \\
\hline P.15\% & 2,934 & $2,908-2,960$ & Bias & $2,900-2.968$ & Bias \\
\hline \multicolumn{6}{|c|}{$B=1.000$} \\
\hline$P .5 \%$ & 2,970 & $2,945-2,994$ & Bias & $2,937-3,002$ & Tidak Bias \\
\hline P.10\% & 2,951 & $2,924-2,977$ & Bias & $2,915-2,985$ & Bias \\
\hline P.15\% & 2,934 & $2,907-2,961$ & Bias & $2,899-2,969$ & Bias \\
\hline \multicolumn{6}{|c|}{$B=5.000$} \\
\hline$P .5 \%$ & 2,970 & $2,946-2,995$ & Bias & $2,938-3,002$ & Tidak bias \\
\hline P.10\% & 2,951 & $2,925-2,977$ & Bias & $2,916-2,986$ & Bias \\
\hline P.15\% & 2,934 & $2,907-2.961$ & Bias & $2,899-2,970$ & Bias \\
\hline \multicolumn{6}{|c|}{$B=10.000$} \\
\hline$P .5 \%$ & 2,970 & $2,946-2,995$ & Bias & $2,938-3,002$ & Tidak bias \\
\hline P.10\% & 2,951 & $2,925-2,978$ & Bias & $2,916-2,986$ & Bias \\
\hline P.15\% & 2,934 & $2,908-2,961$ & Bias & $2,899-2,969$ & Bias \\
\hline \multicolumn{6}{|c|}{$B=50.000$} \\
\hline$P .5 \%$ & 2,970 & $2,946-2,995$ & Bias & $2,938-3,002$ & Tidak bias \\
\hline P.10\% & 2,951 & $2,924-2,977$ & Bias & $2,916-2,986$ & Bias \\
\hline P.15\% & 2,934 & $2,908-2,961$ & Bias & $2,899-2,969$ & Bias \\
\hline \multicolumn{6}{|c|}{$B=75.000$} \\
\hline$P .5 \%$ & 2,970 & $2,946-2,994$ & Bias & $2,938-3,002$ & Tidak bias \\
\hline P.10\% & 2,951 & $2,925-2,977$ & Bias & $2,916-2,986$ & Bias \\
\hline P.15\% & 2,934 & $2,908-2,961$ & Bias & $2,899-2,969$ & Bias \\
\hline \multicolumn{6}{|c|}{$B=100.000$} \\
\hline$P .5 \%$ & 2,970 & $2,946-2,994$ & Bias & $2,938-3,002$ & Tidak bias \\
\hline P.10\% & 2,951 & $2,925-2,977$ & Bias & $2,916-2,986$ & Bias \\
\hline P.15\% & 2,934 & $2,908-2,961$ & Bias & $2,899-2,969$ & Bias \\
\hline
\end{tabular}

Tabel 5. Pendugaan Parameter $\beta_{1}=5$ dengan Bootstrap Residual

\begin{tabular}{|c|c|c|c|c|c|}
\hline \multirow{2}{*}{$\begin{array}{l}\text { Jumlah } \\
\text { pencilan }\end{array}$} & \multirow{2}{*}{$\widehat{\beta_{1}}$} & \multicolumn{2}{|c|}{ Selangkepercavaan $95 \%$} & \multicolumn{2}{|c|}{ Selangkepercavaan $99 \%$} \\
\hline & & $\begin{array}{c}\text { Selang } \\
\text { keppercayaan }\end{array}$ & Keterangan & \begin{tabular}{|c|} 
Selang \\
Kepercayaan
\end{tabular} & Keterangan \\
\hline \multicolumn{6}{|c|}{$B=250$} \\
\hline P.5\% & 4,970 & $4,944-4,996$ & Bias & $4,935-5,005$ & Tidak bias \\
\hline P.10\% & 4,951 & $4,924-4,979$ & Bias & $4,916-4,988$ & Bias \\
\hline P.15\% & 4,932 & $4,906-4,958$ & Bias & $4,898-4,966$ & Bias \\
\hline \multicolumn{6}{|c|}{$B=500$} \\
\hline P.5\% & 4,970 & $4,944-4,996$ & Bias & $4,936-5,004$ & \begin{tabular}{|l} 
Tidak bias \\
\end{tabular} \\
\hline P.10\% & 4,951 & $4,923-4,976$ & Bias & $4,915-4,985$ & Bias \\
\hline $15 \%$ & 4,932 & $4,907-4,959$ & Bias & $4,899-4,967$ & Bias \\
\hline \multicolumn{6}{|c|}{$\mathrm{B}=1.000$} \\
\hline$P .5 \%$ & 4,970 & $4,946-4,995$ & Bias & $4,938-5,003$ & Tidak bias \\
\hline P.10\% & 4,951 & $4,924-4,978$ & Bias & $4,915-4,986$ & Bias \\
\hline $15 \%$ & 4,932 & $4,905-4,958$ & Bias & $4,897-4,967$ & Bias \\
\hline \multicolumn{6}{|c|}{$B=5.000$} \\
\hline $\mathrm{P} .5 \%$ & 4,970 & $4,945-4,995$ & Bias & $4,937-5,003$ & Tidak bias \\
\hline P.10\% & 4,951 & $4,923-4,979$ & Bias & $4,914-4,988$ & Bias \\
\hline P.15\% & 4,932 & $4,905-4,960$ & Bias & $4,896-4,968$ & Bias \\
\hline \multicolumn{6}{|c|}{$B=10.000$} \\
\hline $\mathrm{P} .5 \%$ & 4,970 & $4,945-4,995$ & Bias & $4,937-5,003$ & Tidak bias \\
\hline P.10\% & 4,951 & $4,923-4,979$ & Bias & $4,914-4,987$ & Bias \\
\hline P.15\% & 4,932 & $4,905-4,959$ & Bias & $4,897-4,968$ & Bias \\
\hline \multicolumn{6}{|c|}{$B=50.000$} \\
\hline $\mathrm{P} .5 \%$ & 4,970 & $4,944-4,995$ & Bias & $4,936-5,003$ & Tidak bias \\
\hline P.10\% & 4,951 & $4,923-4,979$ & Bias & $4,914-4,988$ & Bias \\
\hline P.15\% & 4,932 & $4,905-4,959$ & Bias & $4,896-4,968$ & Bias \\
\hline $\mathrm{P} .5 \%$ & 4,970 & $4,944-4,995$ & Bias & $4,936-5,003$ & Tidak bias \\
\hline P.10\% & 4,951 & $4,923-4,979$ & Bias & $4,914-4,988$ & Bias \\
\hline P.15\% & 4,932 & $4,905-4,959$ & Bias & $4,896-4,968$ & Bias \\
\hline \multicolumn{6}{|c|}{$B=75.000$} \\
\hline$P .5 \%$ & 4,970 & $4,945-4,995$ & Bias & $4,937-5,003$ & Tidak bias \\
\hline P.10\% & 4,951 & $4,923-4,979$ & Bias & $4,914-4,987$ & Bias \\
\hline P.15\% & 4,932 & $4,905-4,959$ & Bias & $4,896-4,968$ & Bias \\
\hline \multicolumn{6}{|c|}{$B=100.000$} \\
\hline$P .5 \%$ & 4,970 & $4,945-4,995$ & Bias & $4,937-5,003$ & Tidak bias \\
\hline P.10\% & 4,951 & $4,923-4,979$ & Bias & $4,914-4,987$ & Bias \\
\hline P.15\% & 4,932 & $4,905-4,959$ & Bias & $4,896-4,968$ & Bias \\
\hline
\end{tabular}

Data simulasi yang telah diresampling dengan metode bootstrap residual, asumsi kenormalannya diuji dengan Uji AndersonDarling. 
Tabel 6. Pengujian Asumsi Kenormalan pada Data yang Telah Diresampling dengan Uji Anderson-Darling

\begin{tabular}{|c|c|c|c|}
\hline Jumlah pencilan & Alpha $(\mathrm{a})$ & $p$-value & Keputusan \\
\hline \multicolumn{4}{|c|}{$\beta_{1}=1$} \\
\hline P.5\% & 0,05 & 0,0007996 & Tidak nomal \\
\hline P.10\% & 0,05 & 0,02893 & Tidak nomal \\
\hline P.15\% & 0,05 & 0,05444 & Normal \\
\hline \multicolumn{5}{|c|}{$\beta_{1}=3$} \\
\hline P.5\% & 0,05 & 0,002637 & Tidak nomal \\
\hline P.10\% & 0,05 & 0,01204 & Tidak nomal \\
\hline P.15\% & 0,05 & 0,06061 & Nomal \\
\hline \multicolumn{5}{|c|}{$\beta_{1}=5$} \\
\hline P.5\% & 0,05 & 0,003931 & Tidak nomal \\
\hline P.10\% & 0,05 & 0,01703 & Tidak nomal \\
\hline P.15\% & 0,05 & 0,01663 & Tidak nomal \\
\hline
\end{tabular}

Berdasarkan Tabel 6 dapat dilihat bahwa pada data simulasi berpencilan $15 \%$ dengan $\beta_{1}$ $=1$ dan $\beta_{1}=3$, nilai $-p$-value yang dihasilkan lebih besar dari alpha $(\alpha)$ 0,05 sehingga dapat disimpulkan bahwa data menyebar normal. Pada data berpencilan 5\% dan $10 \%$ p-value lebih kecil dari alpha $(\alpha) 0,05$ sehingga dapat disimpulkan data tidak mengikuti sebaran normal. Pada data simulasi dengan nilai $\beta_{1}=5$, data simulasi dengan pencilan $5 \%, 10 \%$, dan $15 \%$ tidak menyebar normal.

\section{Menganalisa dan Membandingkan Hasil \\ Pendugaan Parameter $\beta_{1}$ dengan MKT dan Metode Bootstrap Residual}

Berdasarkan Tabel 3, 4, dan 5 dapat dilihat bahwa penduga parameter yang dihasilkan oleh metode bootstrap residual tidak berbeda jauh dengan penduga parameter yang dihasilkan oleh MKT. Hal ini juga dapat menunjukkan bahwa metode bootstrap residual merupakan penduga yang akurat untuk menduga parameter regresi.

Penduga parameter yang dihasilkan oleh MKT dan bootstrap residual sama-sama menghasilkan penduga parameter yang bias pada data berpencilan $10 \%$ dan $15 \%$. Dapat dilihat pada data simulasi dengan nilai $\beta_{1}=1$ bahwa data dengan pencilan $5 \%$ pada selang kepercayaan $95 \%$, penduga parameter yang dihasilkan menjadi tidak bias pada resampling ke 250 sampai 100.000. Pada data simulasi dengan nilai $\beta_{1}=5$, data dengan pencilan $5 \%$ pada selang kepercayaan $99 \%$, penduga parameter yang dihasilkan oleh bootstrap residual menjadi tidak bias. Hal ini menunjukkan bahwa metode bootstrap residual hanya mampu mengatasi bias pada penduga parameter pada data dengan pencilan sebesar $5 \%$.

Selang kepercayaan yang dihasilkan oleh metode bootstrap residual cenderung stabil. Dapat dilihat pada selang kepercayaan 95\% dan 99\% yang dihasilkan tidak ada perubahan yang signifikan walaupun telah diresampling sampai 100.000 kali. Hanya saja selang kepercayaan yang dihasilkan metode bootstrap residual memiliki kisaran selang yang lebih lebar dari MKT.

Pada MKT uji kenormalan dilakukan pada sisaan yang dihasilkan oleh model regresi, di dapat kesimpulan bahwa pada data simulasi dengan nilai $\beta_{1}=1, \beta_{1}=3$, dan $\beta_{1}=5$, data tanpa pencilan menyebar normal sedangkan data dengan pencilan 5\%,10\%, dan 15\% tidak menyebar normal. Setelah mengalami proses bootstrap, data simulasi diuji kembali kenormalannya dengan uji Anderson-Darling. Hasil yang didapat tidak berbeda jauh dengan uji kenormalan pada MKT, hanya saja pada data berpencilan $15 \%$ pada $\beta_{1}=1$ dan $\beta_{1}=3$, data mengikuti sebaran normal. Hal ini dikarenakan sampel yang berasal dari populasi yang menyebar normal, setelah mengalami proses resampling yang terus-menerus dilakukan mengakibatkan asumsi kenormalan pada data terpenuhi.

\section{SIMPULAN DAN SARAN}

Dari hasil yang diperoleh dapat disimpulkan bahwa jumlah pencilan yang hanya 5\% dari jumlah data setelah diresampling dengan bootstrap residual mampu menghasilkan penduga parameter dan selang kepercayaan yang mendekati pendugaan awalnya, sehingga penduga yang dihasilkan menjadi tidak bias. Pada penduga parameter 
untuk data dengan pencilan $10 \%$ dan $15 \%$ yang terletak pada gugus bawah data, bias pada penduga parameter tidak dapat teratasi.

Saran yang dapat diberikan pada penelitian ini yaitu pada data simulasi yang digunakan, pencilan dibangkitkan dengan data sisaan, pada penelitian selanjutnya pencilan dapat dibangkitkan pada peubah bebas dan dengan menggunakan analisis regesi linier berganda, regresi logistik, dan analisis regresi lainnya. Pada penelitian ini, bias penduga parameter disebabkan oleh adanya pelanggaran asumsi kenormalan akibat pencilan. Penelitian selanjutnya mengamati bias yang disebabkan pelanggaran asumsi-asumsi lainnya.

\section{DAFTAR PUSTAKA}

[1] Neter, J., Wasserman, W. \& Kutner, M.H., 1997. Model Linear Terapan Buku I: Analisis Regresi Linear Sederhana.(Terjemahan Bambang Sumantri). 3rd ed. Bandung: Jurusan Statistika FMIPA-IPB.

[2] Efron, B. \& Tibshirani, R.J., 1993. An Introduction to the Bootstrap. New York: Chapman \& Hall, Inc.

[3] Sungkono, J., 2013. Resampling Bootstrap pada R. Magistra No.84 Th.XXV Juni 2013, pp.47-54. 